\title{
SAVING PATTERN OF SMALL-SCALE WOMEN RICE FARMERS IN SAN JOSE, OCCIDENTAL MINDORO
}

\author{
Mary Yole Apple Declaro Ruedas, Mary Joy Guico
}

Occidental Mindoro State College, San Jose, Occidental Mindoro, Philippines

*Corresponding author: tsinelas.yole@gmail.com

Citation: Ruedas, M.Y.A.D., and Guico, M.J. 2021. Saving Pattern Of Small-Scale Women Rice Farmers In San Jose, Occidental Mindoro. J. Asian Rur. Stud. 5(1): 48-55

\begin{abstract}
The study aims to assess the saving and investment pattern of women rice farmers in San Jose, Occidental Mindoro. The study was conducted in the rice-producing barangays of San Jose, Occidental Mindoro, namely: Mabini, Mapaya, and Mangarin from February to July 2017. The study population included all women farmers who were involved in different rice farming activities from production to marketing. The 48 respondents were randomly selected. Informed consent was sought before the conduct of the study. Descriptive statistics like mean, percentages, and frequency distribution were used to assess the women farmers' profile. While Pearson Moment Correlation was used to test the relationship between the variables. The result shows that the small-scale women farmers have a small household size and small farm sizes with an income above the poverty threshold. They "sometimes" save through cash and "frequently" save through non-cash. They "frequently" encountered problems in saving capacity. Further, farm size is significantly related to the savings pattern of women rice farmers. Socio-economic characteristics have no relationship with constraints to saving capacity. The study suggests using other variables to further determine the saving pattern and saving capacity of the women rice farmers.
\end{abstract}

Keywords: Saving Capacity; Cash; Non-Cash

\section{Introduction}

Recent reports show that a big chunk of the Filipino rice farmer still lives below the poverty line with income from rice farming inadequate to cover the minimum subsistence level requirement. Growing rice can be tough and daunting especially for small-scale farmers; but when it wisely managed, it can be a goldmine (IRRI, 2010).

With the high cost of living nowadays, farmers must start integrating other commodities in their rice farms so that they will have other sources of income while waiting for the rice harvest (Provido, 2013). Increase family income will ensure better family nutrition (better food) children education, improved living conditions (people usually improve their income, fix leaking roofs, etc.) expansion of business and arise out of poverty (IRRI, 2012).

Rice farmers face many problems that limit their possibilities for growth. The loans will reduce the farmers' finance cost from money lenders and provide additional savings. Each farmer should expect more than $\$ 100$ in savings or increase income from loans, up to $10 \%$ of their annual income (PCARRD, 2000). The vast majority of lending 76\% was provided to households in the wealthiest quartile (Fukui, 2003).

The farm household had an average of five members, two of whom worked on the farm. Household average annual income was $P$ 158,793, about half of which came from sources (PCARRD, 2011). For most households, income is the most important source of wealth. The 40 percent of households with the least assets -their consumer debts exceeded their gross assets. Increase of saving, even among lower-income; do not confront such substantial 
barriers. While debt-financed consumption is pleasurable, it does not appear to be physically addictive (Brown, 2014).

The role of household savings is a key element in analyzing both debt and spending household savings rate as a percent of disposable income was consistently between $7 \%$ and $11 \%$. However, as income growth started to slow down, consumer increasingly maintains their old spending habits by going into more debt and reducing their saving life (Calmus, 2012).

In rural areas of Lao PDR, savings are mostly in-kind-non cash savings account for $73.3 \%$ of total savings in rural areas. Non-cash savings exceed cash savings for each wealth quartile, and for three of rural strata. Livestock is the most common means of non- cash savings in Lao rural households, used by $98.2 \%$ of those households (Fukui, 2003).

Real income improves and poverty declines across household groups, but the net effects are lower in lower in rural than urban households. The impact of the free world trade economy is favourable in terms of higher export demand for agriculture-related effects against agriculture, and therefore favourable to the rural household (Cororaton, 2000). In the meanwhile, this indicates the forces affecting the overall economy, including productivity, financial innovation income, and wealth distribution may affect the rate of savings (Poterba, 2000).

A rapid rise in the savings ratio can cause a fall aggregate demand and recession, a higher savings ratio is often considered to help promote more sustainable economic growth (Pettinger, 2014). Rural incomes are unstable and irregular because of the nature of agriculture work. Climate conditions and the cyclical or unpredictable nature of agriculture markets have a major impact at times violent and often unexpected on the savings capacity rural population, thus hampering savings accumulation and collection (Sidibe, 2011).

Bersales and Mapa (2006) posited that while the impact of saving at the macro level is well documented, the micro aspect of saving or the saving behavior of households is not well understood and, in the Philippines, is not well studied. In 1987, Rodriguez and Meyer (1988) studied the saving behavior of rural households in the Philippines and found that income, household size and education of the household head could have positive effect in raising savings in the rural communities.

Thus, this paper aims to assess the saving pattern of women rice farmers in selected barangays in San Jose, Occidental Mindoro. Specifically, it aims to: determine the socioeconomic characteristics of the women farmers; determine the savings pattern and constraints to saving capacity of the women rice farmers in farm activities; and determine the relationship between socio-economic characteristics and the savings pattern of women rice farmers in farm activities.

\section{Methodology}

The study was conducted in the rice-producing barangays of San Jose, Occidental Mindoro, namely: Mabini, Mapaya, and Mangarin from February to July 2017. The study population included all women farmers who were land owners and were involved in different rice farming activities from production to marketing in the last two years. The 48 respondents were randomly selected from the list of farmers in the barangays. Informed consent was sought before the conduct of the study.

A self-constructed questionnaire was used in gathering data. The questionnaire consisted of three parts, namely, Part I- socio-economic characteristics of the women rice farmers, Part II-savings avenue of the small-scale women rice farmers; and Part III- small-scale women farmers' constraints to saving capacity. Descriptive statistics like mean, percentages, and 
frequency distribution were used to assess the women farmers' profile. While, Pearson Moment Correlation was used to test the relationship between the variables.

\section{Results and Discussion}

\section{Socio-economic characteristics of the women rice farmers}

Table 1 shows the profile of 48 women-farmers in the rice-producing barangays of San Jose, Occidental Mindoro, namely: Mabini, Mapaya, and Mangarin. The women-farmers have a medium household size with an average of 5.23 members. This is above the average household size in 2015 which stood at 4.4 members. It could be deduced that rural farm women had large household sizes to be able to provide enough labour for agricultural production. This scenario is responsible for the high rate of malnutrition, mortality, illiteracy, unemployment especially in the rural economy hence leading to a change in family emphasis (Okorji, 1999).

The average monthly income, which stood at $\mathrm{PhP} 7,043.00$ falls above the poverty threshold of the province which is PhP 17,411.60 annually (PSA, 2012). While, their average monthly savings from cash-income amounts to $\mathrm{PhP} 789.13$, which is $8.9 \%$ of their monthly income. The poverty incidence among households in MiMaRoPa is 22 percent in 2015. This means that 1 out of 5 families had an income lower than the poverty threshold or the minimum income to meet the basic food and non-food necessities.

This shows that income is an important determinant of the saving behavior of the rural households. Income is a positive factor that analyses the savings of a country or a household. The rural households experience a very low level of income as many of the rural families earn their livelihoods from the agriculture, many are daily wage workers, petty traders and other self-employed activities. The level of income is very low but the marginal propensity to consume is very high among these categories of people. So, the saving rate of those households are very low as shown in the result of the study which is only $\mathrm{PhP} 100-1500.00$ (approx. USD 2-31) monthly.

They are smallholder farmers with an average farm size of 2.50 hectares ranging from 1-6 hectares. Based on the Agriculture and Fisheries Modernization Act (AFMA) or RA 8435 of 1997 and the Magna Charta of Small Farmers (RA 7607) of 1993, the country defines smallholder "as natural persons dependent on small-scale subsistence farming as their primary source of income". On the other hand, the Land Bank of the Philippines defines small farmers as actual tillers of lands, not over 5 hectares. As such, their importance derives from the prevalence, their role in agricultural and economic development, and the concentration of poverty in the rural areas. Three-fourths of the world's poor live in rural areas wherein smallholder farming is their only main economic subsistence.

Table 1. Socio-economic characteristics of the small-scale women rice farmers.

\begin{tabular}{lcc}
\hline \multicolumn{1}{c}{ Profile } & Mean & Range \\
\hline Household size & 5.23 members & $3-7$ members \\
Monthly income & PhP 7,043.00 & PhP 6,000-18,000.00 \\
Monthly savings from income (cash) & PhP 789.13 & PhP 100.00-1500.00 \\
Farm size & 2.50 ha & $1-6$ ha \\
\hline
\end{tabular}




\section{Savings patterns of women rice farmers}

Savings can be known as the cash or physical products set aside for future use. People in rural and other low-income communities can save when they are guided and encouraged by the Government and financial institutions. The people in rural areas, savings are made through traditional credit rotation groups, or purchase of domestic animals (goats, pigs, chickens or cows). Gradually, the traditional way of saving in rural region has been abolished; the people shifted their saving pattern to save in form of physical assets, like gold, land and durable goods and financial assets like shares, stocks, and bonds (Nayak, 2013).

The study identified that there are principally two major ways through which women farmers save their finances, which includes cash and non-cash (kind) forms. The cash methods of saving include saving through banks, microfinance institutions, money lending, and cooperative/associations. The non-cash methods of saving include; the purchase of land, storage of agricultural produce, livestock investment, education for children, and building of houses.

The result shows that the non-cash method was the "frequently" (mean=3.60) employed saving method by the women farmers in the area. However, the "always" non-cash methods of saving were the storage of farm produce (mean=4.53), and the education of children (mean=4.53).

Saving financial resources in the house as the "always employed" (mean=4.54) saving avenue is one of the oldest traditional methods of saving among farming households in rural areas. The essence of a high prevalence of this form of saving can be attributed to the bureaucratic bottleneck involved in the bank saving, and the fear of being duped by financial intermediaries. Again, to maintain high liquidity with which immediate problems can be solved; to avoid traveling a far distance to withdraw cash from financial institutions can also be attributed to the finding.

Odoemenem, et al. (2005) explained that farmers make use of informal financial sectors to save because it gives them access to loans that they cannot get from formal financial institutions due to lack of collateral.

Table 2. Savings avenue of the small-scale women rice farmers.

\begin{tabular}{|c|c|c|c|}
\hline \multicolumn{2}{|l|}{ Avenue } & Mean & Range \\
\hline \multicolumn{4}{|l|}{$\overline{\text { Cash }}$} \\
\hline Bank & & 1.68 & Occasionally \\
\hline House saving & & 4.54 & Always \\
\hline Microfinance institutions & & 3.78 & Frequently \\
\hline People & & 1.23 & Never \\
\hline Cooperative/associations & & 3.23 & Sometimes \\
\hline & Sub mean & 2.88 & Sometimes \\
\hline \multicolumn{4}{|l|}{ Non-Cash } \\
\hline Purchase of land & & 3.67 & Frequently \\
\hline Storage of farm produce & & 4.53 & Always \\
\hline Livestock investment & & 2.78 & Sometimes \\
\hline Building of house & & 2.50 & Occasionally \\
\hline Education of children & & 4.53 & Always \\
\hline & Sub mean & 3.60 & Frequently \\
\hline
\end{tabular}

Legend: $0.50-1.50=$ Never; $1.51-2.50=$ Occasionally; $2.51-3.50=$ Sometimes; $3.51-4.50=$ Frequently; 4.51-5.00= Always 
The women rice farmers "always" save money in a monthly bases, that is deposited in micro lending institutions like CARD Bank, Taytay sa Kauswagan and other "paluwagan" schemes. Paluwagan is a common Filipino financial term. The idea revolves around a group of people paying the same amount of money on either a daily/weekly/monthly basis wherein each member is being paid (mostly the total amount of money collected on the given pay in) on the desired date and time by the group. It is like pool saving wherein you save together with a group and reap what you saved on a date and time set. While, non-cash savings in form of land, livestock and education were done semi-annually or every cropping period wherein the cash flow is higher as compared to the other months of the year.

Table 3. Savings pattern of the small-scale women rice farmers.

\begin{tabular}{llcc}
\hline \multicolumn{1}{c}{ Avenue } & Mean & Range \\
\hline Cash & & 1.08 & Never \\
& Weekly & 4.54 & Always \\
Monthly & 2.58 & Sometimes \\
Semi-annually (per cropping) & 1.08 & Never \\
Annually & Sub mean & $\mathbf{2 . 3 2}$ & Occasionally \\
& & \\
Non-Cash & 1.08 & Never \\
Weekly & 1.08 & Never \\
Monthly & 4.48 & Frequently \\
Semi-annually (per cropping) & 2.58 & Sometimes \\
Annually & & $\mathbf{2 . 3 0}$ & Occasionally \\
& & Sub mean
\end{tabular}

Legend: $0.50-1.50=$ Never; $1.51-2.50=$ Occasionally; $2.51-3.50=$ Sometimes; $3.51-4.50=$ Frequently; 4.51-5.00= Always

\section{Small-scale women farmers' constraints to saving capacity}

According to Kibet et al (20090, saving is therefore an important budget item for all households, which proves that poor households do also save because other factors other than income influence saving. Thus, farmers' saving could be a result of relatively irregular source of monthly income.

Komicha (2007) had explained the farm household economic behaviour with reference to saving, credit and production efficiency in two districts of south-eastern Ethiopia. Result shows that about $62 \%$ of the farm households had savings in financial and physical assets but almost all farm households (about 90\%) had savings held informally. It could be noted that that financial institutions with easy access, low transaction costs, higher real returns on savings and convenient withdrawal of savings may provide incentives for those who hold financial savings informally to channel their savings into the formal institutions.

Result shows that the always constraints to saving capacity were the delay or waste of time involved in putting and withdrawing saving from the institution (mean=4.56) and bureaucracy involved in opening bank account (mean=4.56). This supported the study of Osondu, Obike, \& Ogbonna (2015) that the main constraint to the small holder farmers' inability to save is inadequacy of income. Remoteness of banks was also found to hinder the small holder farmers saving abilities. Another hindrance to the small holder farmers' ability to save also has to do with the fear that their monies will not be safe if they save it in both formal and informal forms. 
Table 4. Small-scale women farmers' constraints to saving capacity.

\begin{tabular}{|c|c|c|}
\hline Constraints to saving capacity & Mean & Range \\
\hline $\begin{array}{l}\text { Inadequate income due to lack of access to } \\
\text { productive resources and low returns. }\end{array}$ & 3.72 & Frequently \\
\hline High consumption rate out of available income & 4.48 & Frequently \\
\hline $\begin{array}{l}\text { Lack of skilled due to low levels of literacy and } \\
\text { formal education }\end{array}$ & 3.27 & Sometimes \\
\hline Lack of access to banks or financial services & 2.23 & Occasionally \\
\hline Low interest paid on saving by the bank & 3.53 & Frequently \\
\hline Fear of bank failure & 3.67 & Frequently \\
\hline $\begin{array}{l}\text { Delay or waste of time involved in putting and } \\
\text { withdrawing saving from the institution }\end{array}$ & 4.56 & Always \\
\hline Bureaucracy involved in opening bank account & 4.56 & Always \\
\hline Grand mean & 3.76 & Frequently \\
\hline
\end{tabular}

Legend: $0.50-1.50=$ Never; $1.51-2.50=$ Occasionally; $2.51-3.50=$ Sometimes; $3.51-4.50=$ Frequently; 4.51-5.00= Always

Relationship between socio-economic characteristics and the savings pattern of women rice farmers in farm activities

Abid and Afridi (2010) analyzed the saving behavior of household in urban and rural areas of District Muzaffarabad, AJ\&K. Result shows that there exist a strong relationship between the saving behavior of households and proposed variables. Moreover, income and locality have a positive effect on saving behavior of household whereas; education and family size have a negative effect on saving behavior of the household. It means whenever income of people increases, saving will also increase and people in rural areas save more than people in urban areas. On the other side, large family size and more educated people save less.

Burns and Dwyer (2007), posited that saving is affected by the age group of the population that could affects the development of a country through investment. However, the result of the findings revealed that only farm size of the women-farmers influenced their saving pattern at a 5\% level of significance.

Table 5. Relationship between socio-economic characteristics and the savings pattern of women rice farmers in farm activities.

\begin{tabular}{lccc}
\hline \multicolumn{1}{c}{$\begin{array}{c}\text { Socio-demographic } \\
\text { characteristics }\end{array}$} & \multicolumn{2}{c}{ Savings Pattern } & \\
\cline { 2 - 3 } & Computed $\boldsymbol{r}$ & Critical $\boldsymbol{r}$ & Interpretation \\
\hline Household size & 0.021 & 0.257 & Not Significant \\
Monthly income & 0.163 & 0.257 & Not Significant \\
Farm size & 0.362 & 0.257 & Significant \\
\hline
\end{tabular}

\section{Conclusions}

The study has the following conclusions that the small-scale women farmers have small household size and small farm sizes with an income above the poverty threshold. They "sometimes" save through cash and "frequently" save through non-cash. They "frequently" encountered problems in saving capacity. Farm size is significantly related to the savings pattern of women rice farmers. 


\section{Recommendation}

The study suggests using other variables to further determine the saving pattern and saving capacity of the women rice farmers.

\section{References}

Abid, S. and Afridi, G.S. (2010) Assessing the Household Saving Pattern of Urban and Rural Households in District Muzaffarabad. Pakistan Journal of Life and Social Sciences, 8, 137-141.

Bautista, M.R. \& Lamberte, M.B. (1990). Comparative Saving of Behaviour of Rural and Urban. Journal of the Philippine Development. opendocs: ids.ac.uk/.pidswp 9015.pdf.

Bersales, L., \& Mapa, D. (2006). Patterns and determinants of household saving in the Philippines . USAID Philippines. http://pdf.usaid.gov/pdf_docs/PNADH621.pdf

Brobeck S. (2014).Research Spotlight Define Benefit Pensions and Household .http\| www.bea gov.||.0806.benefits.pd

Brown, C.K. (1999). Rural Development and Strategies with Special Reference to Ghana. International Institute of Rural Reconstruction and Ghana Rural Reconstruction. United State Agency for International Development, Washington D.C.

Calmus, R. (2012). Improving Economic Mobility through Increase Savings. www.heritage.org|.improving-economy

Cororaton, B.C.( 2000), Philippine Rice and Rural Poverty: An impact analysis of market reform using CGE. www.ifri.org/sites/default/files/publication/mtidp96.pdf

International Rice Research Institute (IRRI).(2010).Rice Production in the Philippines, http:irri.com

International Rice Research Institute (IRRI).(2012). Rice a Filipino Constant Bureau of Agricultural Research. http: |www.bar.gov.ph

Fukui R, (2003), Development of Microfinance Project. http:||www.First Initiative.org

Kibet, L., Mutai, B., Ouma, D., Ouma, S., \& Owuor, G. (2009). Determinants of household saving: Case study of smallholder farmers, entrepreneurs and teachers in rural areas of Kenya. Journal of development and agricultural economics, 1, 137-143.

Komicha, H. (2007), "Farm Household Economic Behaviour in Imperfect Financial Markets", Doctoral thesis, Acta Universitatis Agriculturae Sueciae, 2007: 78.

Nayak, S. (2003). Determinants and Pattern of Saving Behaviour in Rural Households of Western Odisha. A Thesis Submitted for the Partial Fulfillment of the Master Degree in Development Studies. National Institute of Technology Rourkela - 769008, India

Okorji, E.C. (1999). Consequences of Agricultural Productivity of Crops Stereotyping along sexline, Anambra State. M.Sc. Thesis, Department of Agricultural Economics, University of Nigeria, Nssuka, Enugu State, Nigeria.

Odoemenem, I.U. Ezike, K.N.N., Alimba, J.O. (2005), Assessment of Agricultural Credit Availability to Small-scale Farmers in Benue State. Journal of Agricultural Science and Technology, Vol. 15(1\&2) pp. 79-87.

Osondu, C., Obike, C., \& Ogbonna, S. (2015). Savings, Income And Investment Patterns And Its Determinants Among Small Holder Arable Crop Farmers In Umuahia Capital Territory, Abia State Nigeria. European Journal of Business and Innovation Research Vol.3, No.1 
Pettinger, T.R.(2014).Saving Ratio..UK.|Economics help.www. Economic helps

Philippine Council for Agriculture and Natural Resources Research and Development (PCARRD).(2011).the Farm Level Impact of the Techno Gabay Program: Assessment Evidence and Implication. PCARRD Series No. 122.

Rodriguez, J. and Meyer, R. (1988). "The Analysis of Saving Behavior: The Case of Rural Households in the Philippines." The Philippine Institute for Development $\begin{array}{llllr}\text { Studies (PIDS) } & \text { Working } & \text { Paper } & \text { No. }\end{array}$ (http://dirp4.pids.gov.ph/ris/wp/pidswp8820.pdf).

Sidibe, A. (2011). Can Collecting Savings in Rural Areas Be Profitable. www.cgap.org Sikarwar, D.H. (2014). Government may increase individual articles Tax benefits to boost household saving. Economic times.india times.com 